\title{
Corpo, estupro e processo de não-nomeação em Cidade de deus
}

Body, rape and non-nomination process in Cidade de Deus

\author{
Fernanda Surubi Fernandes ${ }^{1}$ \\ Universidade Estadual de Goiás - UEG/Unidade de Iporá \\ fernanda.fernandes@ueg.br \\ Olimpia Maluf Souza ${ }^{2}$ \\ Universidade do Estado de Mato Grosso - UNEMAT \\ olimpiamaluf@gmail.com
}

RESUMO: Este estudo tem como objetivo analisar o funcionamento discursivo do estupro em Cidade de Deus, a partir do dispositivo teórico e metodológico da Análise de Discurso. Ao observar o discurso fílmico, compreendemos que a relação sujeito e corpo constitui um olhar sobre a violência contra a mulher, materializando no filme, pela cena do estupro e pelo processo de não-nomeação, a interdição do desejo feminino, da opressão sofrida pela mulher, da objetificação dos corpos e das relações de força, que se marcam pela divisão dos sentidos.

Palavras-chave: Sujeito; Corpo; Interdição.

ABSTRACT: This study aims to analyze the discursive functioning of rape in Cidade de Deus, from the theoretical and methodological device of Discourse Analysis. When observing the filmic discourse, we understand that the relationship between subject and body constitutes a look at violence against women, materializing in the film, the rape scene and the process of nonnomination, the interdiction of female desire, the oppression suffered by women, the objectification of bodies and the relations of force, which are marked by the division of the senses.

Keywords: Subject; Body; Interdiction.

\footnotetext{
${ }^{1}$ Professora na área de Língua Portuguesa e Linguística da Universidade Estadual de Goiás - UEG, no curso de Letras/Campus Oeste/Unidade de Iporá. Doutora em Linguística pela Universidade do Estado de Mato Grosso UNEMAT.

${ }^{2}$ Professora do Programa de Pós-graduação Stricto Sensu em Linguística da Universidade do Estado de Mato Grosso - UNEMAT. Possui graduação em Psicologia pela Universidade de Uberaba (1982), Mestrado (2000) e Doutorado (2004) em Linguística pela Universidade Estadual de Campinas - UNICAMP.
} 


\section{Considerações iniciais}

A análise de filmes tem nos apresentando diferentes perspectivas para discutir sobre a relação corpo, mulher e violência. Essa foi nossa abordagem no projeto de pesquisa sobre a sétima arte em discurso, em que analisamos diversos filmes que tratam sobre a problemática da violência contra a mulher como também da questão do corpo e da violência.

Para este estudo, apresentamos a análise de um desses filmes, com o objetivo de compreender o funcionamento discursivo da violência, em uma cena de estupro, presente no filme Cidade de Deus, observando de que modo os sentidos de violência são produzidos na materialidade fílmica que, de acordo com Milanez e Bittencourt (2012), se constitui pelo olhar da câmera, pelo modo em que as imagens se apresentam, são organizadas para produzir a cena. "Tomando a câmera como a extensão do corpo, serão as determinações corporais de um sujeito que vê o mundo por meio de maneira controlada e reduzida aos campos de visão dentro do enquadramento de uma lente" (MILANEZ; BITTENCOURT, 2012, p. 11), assim, essa relação se constitui a partir do que pode e deve ser dito sobre as imagens numa relação entre o sujeito e corpo, produzindo sentidos.

Esses conceitos são tomados a partir da base teórica e metodológica da teoria da Análise de Discurso (PÊCHEUX, 2009; ORLANDI, 2007a; 2007b), assim, o sujeito é compreendido enquanto posição entre outras. O sujeito se constitui no momento que fala, que diz, pois é dessa maneira que ele significa e é significado na/pela língua. Pensando nessa relação entre sujeito e língua, buscamos compreender como a mulher é significada pela/na língua, na materialidade fílmica, e, desse modo, como os sujeitos e sentidos são constituídos, numa relação de constitutividade entre a memória e a atualidade (PÊCHEUX, 2008).

Assim, as diferentes posições do sujeito no texto instalam uma multiplicidade de sentidos que se contradizem, se deslocam, se ressignificam, atravessados pelas "formas de assujeitamento ideológicas" (ORLANDI; GUIMARÃES, 2008, p. 54).

No caso do estupro, os sentidos atribuídos se significam de acordo com as relações estabelecidas pelos sujeitos e a situação que concebe o discurso do/sobre o estupro, repetindo, reproduzindo, ressignificando sentidos de violência, de interdição do desejo da mulher, em materiais e materialidades específicas, que se imbricam numa relação com os sentidos produzidos.

Compreendemos que, segundo a Análise de Discurso, a história tem o seu real afetado pelo simbólico, nesse sentido, a análise do corpus busca demonstrar de que forma o discurso relaciona-se a uma ou a várias ideologias, pois, segundo Orlandi (2007a, p. 17), “o discurso é 
o lugar em que se pode observar essa relação de língua e ideologia, compreendendo como a língua produz sentidos por/para os sujeitos".

Observa-se esse funcionamento através das "marcas que atestam a relação do sujeito com seu dizer e, através dele, com o mundo" (ORLANDI; GUIMARÃES, 2008, p. 54). Entretanto, essas "marcas são pistas" que, a partir da análise do analista de discurso, são significadas na relação entre o sujeito e o texto, que se constitui numa prática. Segundo os autores: "Para se encontrar sua regularidade não se analisam seus produtos, mas os processos de sua produção" (ORLANDI; GUIMARÃES, 2008, p. 55).

Ao pensar sobre como a língua significa, como os sentidos são produzidas, a Análise de Discurso coloca em funcionamento conceitos que buscam compreendê-la numa relação com a exterioridade. Segundo Orlandi (2007a), a Análise de Discurso observa o homem falando, e a língua é vista na sua forma material, não significada nela mesma, não transparente, assim, o que a teoria aponta é a opacidade, é a incompletude da língua, seu real. Discutir a língua na sua relação histórica e social, a partir das suas condições de produção em relação à memória discursiva, permite que compreendamos como o sentido faz sentido.

Nessa relação, o modo como o nome significa também é relevante para se refletir sobre o processo de identificação. Por isso que, ao analisar a cena de estupro em Cidade de Deus, observamos que o sujeito-mulher não possui nome, não se diz, não tem voz, portanto, não tem identidade.

Para Guimarães (2005), com o ato de nomear, ao sujeito é atribuído uma identidade, pelo nome próprio, pois significa uma identificação com o social. Desse modo, o fato da personagem feminina violada não possuir nome é significativo para nossa análise, pois os sentidos que se produzem, nessas condições de produção, põem em movimento na história o sujeito-mulher como apenas um objeto, um corpo a ser violentado, para acirrar a luta entre os homens, ou seja, o estupro não tem nada a ver diretamente com sexo, mas com o exercício, com a afirmação do poder de um sobre o outro, assim os desejos e vontades da mulher não são considerados, ou seja, não há escolha, não há voz, não há nomeação do sujeito-mulher.

\section{Corpo e estupro}

Apresentar a problemática do estupro já é em si uma discussão ampla, mas, nessa relação, compreender que a violência do estupro se marca no corpo e no desejo da mulher é entrever o quanto a mulher é/foi interditada em seu próprio desejo, vontades e prazeres. 
Interdição que ocorre também pela ameaça de violência, da realização do estupro, que faz suprimir os desejos, as vontades, para que não seja alvo de estupro. Ou seja, dizeres como "ela estava de roupas curtas", "estava sozinha na rua à noite", materializam sentidos de perigo, que produz como efeito a interdição do comportamento da mulher, que pode silenciar seus desejos, vontades, para se sentir mais segura, entretanto, compreendemos isso como uma violência contra a mulher, que produz efeitos de apagamento de seu próprio desejo.

No século XVI, na França, Vigarello (1009) mostra que o estupro está presente nos textos do direito e é um crime, mas os termos usados, ou as penalidades que se aplicam variam de acordo com a situação. "O estupro, como muitas violências antigas, é severamente condenado pelos textos do direito clássico e pouco penalizado pelos juízes" (VIGARELLO, 1998, p. 14), pois, às vezes, leva-se em conta muito mais o depoimento do estuprador do que o da vítima, que, ao fazer a acusação, é imediatamente tomada como uma pessoa "manchada" e muitas vezes responsável pelo ocorrido.

O estupro torna-se ainda mais condenável quando a vítima é menor de idade e/ou virgem, pois, no caso da virgindade, o que se leva em consideração é o fato de a mulher não estar mais apta ao casamento, pela perda da virgindade. Ou seja, o crime é maior por tornar a jovem uma mulher "perdida" para o casamento, uma vez que, ao invés de ser considerada vítima, ela passa a ser considerada uma mulher "contaminada".

O estupro provoca uma lesão ao mesmo tempo semelhante e diferente das outras. Semelhante porque é o efeito da brutalidade. Diferente porque é muitas vezes pouco consciente no agressor, apagada pela efemeridade do desejo, ao passo que intensifica a vergonha na vítima, a idéia de uma contaminação pelo contato: a indignidade atravessando a pessoa atingida para transformá-la aos olhos dos outros (VIGARELLO, 1998, p. 30).

Em muitos casos, principalmente durante o Antigo Regime, na França do século XVIII, o autor observa uma tentativa de silenciar o estupro usando outros termos, devido ao fato de a mulher ser considerada como propriedade do marido. Assim, como propriedade, o ato de denunciar o crime atingiria principalmente o seu cônjuge. Dessa forma, o estupro foi silenciado especialmente nos autos jurídicos, pois a vítima não era levada em conta, mas o seu proprietário, assim a mulher não tinha voz e era silenciada em seu próprio sofrimento, podemos dizer também em seu desejo.

Nessa relação, a questão do corpo se apresenta como espaço de significação. Ou seja, "não há corpo que não esteja investido de sentidos e que não seja o corpo de um sujeito que se 
constitui por processos de subjetivação nos quais as instituições e suas práticas são fundamentais" (ORLANDI, 2005, p. 10).

Para Perrot (2003, p. 13):

O corpo feminino, no entanto, é onipresente: no discurso dos poetas, dos médicos ou dos políticos; em imagens de toda natureza - quadros, esculturas, cartazes - que povoam as nossas cidades. Mas esse corpo exposto, encenado, continua opaco. Objeto do olhar e do desejo, fala-se dele. Mas ele se cala. As mulheres não falam, não devem falar dele. O pudor que encobre seus membros ou lhes cerra os lábios é a própria marca da feminilidade.

Pela fala da autora, o corpo da mulher é construído nesse paradoxo entre ser exposto e ser silenciado, desejo do outro, silenciando o próprio desejo feminino. "O prazer feminino é negado, até mesmo reprovado: coisa de prostitutas" (PERROT, 2003, p. 16).

Nessa ambivalência, quando pensamos em corpo feminino no Brasil, uma projeção imaginária sobre a mulher se significa, colocando-a, e ao seu corpo, num lugar da sensualidade constitutiva também numa contradição, de liberdade de exposição e de objetificação. Assim, no Rio de Janeiro, por exemplo, a imagem do Carnaval evoca uma memória atravessada pela história, história da escravidão, da colonização, que se constitui como um já-lá, mas que se apaga na evidência do desejo e do prazer do/no corpo da mulher brasileira.

Esse desejo se marca pelo consumo atravessado pelo olhar do outro, muitas vezes do estrangeiro. Segundo Pinto (2016), esse olhar produz sobre/no carnaval carioca um efeito de industrialização que

responde pelos desejos de consumo das imagens que circulam por ela e sobre ela. O carnaval do desfile carioca, por exemplo, é a materialização da indústria que vende e veicula imagens de celebridades e de corpos que dançam, desfilam, representam um sentido de carnaval e de festa, para o deleite do olhar (PINTO, 2016, p. 60).

Entre esses corpos, o corpo feminino é exposto na avenida, na mídia, pela tv e internet, "corpos com fantasias que permitem que seus corpos fiquem mais expostos" (PINTO, 2016, p. 62). Essa visibilidade do corpo da mulher brasileira produz efeitos de sensualidade e sexualidade, mas pelo olhar do outro, que faz escopo sobre todas as mulheres brasileiras, significado durante muito tempo pela imagem da Globeleza.

Para o autor, "o corpo da Globeleza também se mostra como o corpo desejado, sensual, mulato e, claro, o corpo que samba; medidas certas para o carnaval, as quais são 
regularizadas pelo discurso da mídia” (PINTO, 2016, p. 73, grifos do autor). Ou seja, há um processo de legitimação de uma imagem da mulata, do carnaval que significa o sentido de mulher brasileira.

Já as autoras Hashiguti, Lemes e Paiva (2016) analisaram um artigo da revista Época (A culpa é delas) e imagens do movimento \#EuNãoMereçoSerEstuprada, para compreender a objetificação do corpo feminino que coloca numa mesma formulação os termos "estupro" e "merecimento".

No artigo da revista, as analistas observam que há uma recorrência da culpabilização da mulher pela realização do estupro, marcadas nas falas dos comentários sobre o artigo, é no seu modo de vestir que há uma interdição que se relaciona com sua sexualidade, como também a ânsia sexual masculina. Projeções das posições sujeito mulher-objeto de desejo e sujeito homem-realizador do desejo. "A comparação do corpo da mulher a um produto exposto numa vitrine segue, portanto, pareada com a comparação do homem a um ladrão em potencial, que poderia se manifestar frente a um objeto de desejo quando lhe apresentado" (HASHIGUTI; LEMES; PAIVA, 2016, p. 129).

Segundo as autoras, na análise da revista, a sexualidade feminina não é questionada, ou seja, é na tomada de posição do sujeito homem, com seu ímpeto sexual, que se identifica nas formulações que materializam que a culpa do estupro é da mulher, por não se colocar como um corpo dócil, com roupas curtas, despertando o desejo masculino.

Diante dessas análises, compreendemos que, em nosso objeto, o corpo significa no ato de violência, no estupro, que coloca o corpo da mulher constituído em sua opacidade, como não transparente, pois as discursividades sobre a violência e o ato do estupro projetam e constituem sentidos sobre a mulher violentada, assim, quando falamos sobre como o estupro constitui sentidos e sujeitos na violência contra a mulher, a questão do corpo é colocada, mais do que lugar onde se materializa a violência, é um corpo que pode falar e calar. Nessa perspectiva, pensamos sobre os modos como o estupro materializa sentidos e constitui o sujeito-mulher interpelada pelas condições de violência numa cena de Cidade de Deus.

\section{Cinema e discurso: na imbricação material}

Apresentamos, de início, um conceito de cinema que o coloca na relação com o discurso, posto que, "enquanto discurso, [...] [o filme] produz efeitos de sentido, é uma forma de linguagem e, portanto, capaz de mediação, de engendrar processos de significação". 
(COSTA, 2016, p. 168). Esses efeitos de sentido ocorrem na relação entre as diferentes formas materiais: linguagem verbal, sonoridade, enquadramento, movimento da câmera etc., que, por suas constituições, produzem efeitos pelos/nos espectadores. É, portanto, a junção dessas diferentes formas materiais que produzem, conforme Milanez e Bittencourt (2012), a materialidade fílmica, enquanto unidade significante.

Esses modos de dizer dos autores permite-nos relacionar seus conceitos ao de “imbricação material”, pensado por Lagazzi (2009) para ajudar a compreender como as diferentes materialidades podem ser postas em relação, pois a autora define como imbricação material aquilo que é materializado a partir da noção de real da língua e da história, que instala a relação necessária entre incompletude e contradição. Assim, defende que essas noções são constitutivas das diferentes formas materiais e que são colocadas em funcionamento pelo gesto de interpretação, que possibilita o movimento de sentidos. Dessa maneira, tomamos o discurso fílmico como constituído por diferentes materialidades significantes, postas em funcionamento pelo processo de imbricação material, que faz com que as diferentes linguagens se signifiquem mutuamente.

Para Milanez e Bittencourt (2012, p. 8), “os instrumentos para a discussão da materialidade do discurso fílmico e a construção de seus sentidos estão na própria história da Análise do Discurso", uma vez que permite compreender não apenas a linguagem verbal, mas também a não verbal, pois, sendo o discurso efeitos de sentido, as diferentes linguagens significam numa relação com as condições de produção em que estão inseridas, colocando em funcionamento o sujeito, a história e a ideologia, que são constituídos na/pela linguagem, isto é, materializam-se e são simbolizados na/pela língua.

Os autores, ao refletirem sobre o discurso fílmico, mostram o quanto a teoria discursiva pauta-se por um atravessamento histórico e social, produzindo efeitos, a partir de diferentes materialidades:

A teoria do discurso é feita de encontros, cruzamentos da história dos saberes, da produção de conhecimentos sobre o que pode ser enunciado, sobre o que é enunciável em momentos diferentes, construindo o discurso como um campo não apenas de lutas ou batalhas, mas de alianças e articulações que sobrepõem fatos do discurso. Essa presença discursiva pode apenas ser ouvida, vista, sentida, percebida por meio de materialidades (MILANEZ; BITTENCOURT, 2012, p. 10).

São esses movimentos, recortes e seleções que dão visibilidade aos modos pelos quais as diferentes materialidades atuam para produzir efeitos. Assim, séries e filmes representam 
um funcionamento discursivo que (re)significam diferentes práticas, a partir de diferentes perspectivas e condições de produção.

Dessa forma, o modo como os filmes apresentam suas formas, sua linguagem implica em efeitos produzidos, a partir de condições específicas, ou seja, a narrativa fílmica conta uma história, usando de todos os recursos para produzir determinados efeitos, como a trilha sonora específica para aquela cena, esperando provocar uma dada emoção, visto que, por sua estrutura semântica, a cena objetiva um efeito a produzir, o que só é possível na relação de um material significante com outro. Pode-se dizer que a linguagem cinematográfica se constitui tanto pelo que é visível quanto pelo que é silenciado, pelas materialidades significantes postas em relação para produzir diferentes efeitos.

Outro aspecto é apresentado por Martin (2005), pois, para ele, a aparência "realista" que a linguagem fílmica produz é um efeito que se instala de forma a dar realidade à cena, que evoca de tal modo a memória dos sentidos que faz com que a cena se coloque como realidade, como algo que de fato está acontecendo: "A imagem fílmica suscita, no espectador um sentimento de realidade em certos casos suficientemente forte para provocar a crença na existência objectiva do que aparece na tela" (MARTIN, 2005, p. 28, grifos do autor).

Escolhida e composta, a realidade que então aparece na imagem é o resultado de uma percepção subjectiva do mundo, a do realizador. O cinema dá-nos da realidade uma imagem artística, quer dizer, se se reflectir bem, não realista (pense-se na função do grande plano e da música, por exemplo) e reconstruída em função daquilo que o realizador pretende exprimir, sensorial e intelectualmente (MARTIN, 2005 , p. 31, grifos do autor).

A imagem pode produzir tanto o efeito da evidência quanto interdita a possibilidade de outros sentidos, assim, quando o teórico aduz que o resultado é dado pela percepção do realizador, o que coloca em funcionamento é o indivíduo de vontade, com sua ilusão de efetivar e de dar forma às suas intenções.

Contudo, para a análise de discurso, os sentidos são constituídos por processos de significação que produzem diferentes posições-sujeitos, assim são os efeitos produzidos no interlocutor que, suplantando qualquer vontade do plano do empírico, se instala como posição-sujeito, posição constituída pelo/no dizer do outro, que coloca em relação dadas imbricações materiais, que instalam os sentidos e os sujeitos. Ou seja, mesmo que o realizador tenha a intenção de produzir certos sentidos, é na relação com o outro que estes são constituídos. 
Assim, deixar escapar sentidos são apenas sentidos outros, postos como efeitos pelo funcionamento da língua(gem), que coloca em fuga o que é esperado/intencionado pelo sujeito empírico.

\section{Processos de (não) nomeação em Cidade de Deus}

Para este estudo, analisamos uma cena de estupro recortada do filme Cidade de Deus, que projeta sentidos de violência e de (des)identificação do sujeito-mulher pela não nomeação. De acordo com Guimarães, ao falar sobre o processo de designação, compreendemos que:

esta unicidade é um efeito do funcionamento do nome próprio como processo de identificação social do que se nomeia. Isto ganha contornos especiais e muito particulares no caso dos nomes próprios de pessoa porque neste caso o funcionamento do nome se dá no processo social de subjetivação. Ou seja, passa a ser uma questão do sujeito (GUIMARÃES, 2005, p. 36).

A questão da nomeação é um ponto relevante a se destacar. Podemos falar como a mulher historicamente, tem em seu nome a marca de ser propriedade do pai, do marido, ao lhe dar o nome de sua família, no casamento. Essa relação é fortemente marcada e ressignificada quando levamos em consideração a colonização e a escravidão na história do Brasil, pois há aí instalado uma objetificação das escravas, marcadas como seu dono/proprietário, no corpo, pelos castigos, e na alma, pelo apagamento de suas crenças, para implantar outras.

Entretanto, trazemos isso para ressaltar a não nomeação, marcada na própria constituição histórica dos sujeitos no Brasil. Ou seja, quando falamos das mulheres como propriedade de seus pais, maridos, subsumimos nesse discurso mulheres que não fizeram parte dessa constituição no Brasil, as indígenas e as mulheres africanas ou afro-descentes.

Abordamos isso porque ressaltamos uma condição específica materializada pelo desejo interditado das mulheres, em contrapartida, muitos discursos ficam silenciados na própria história do Brasil. Esse funcionamento é marcado pela condição da mulher na cena de estupro do filme brasileiro Cidade de Deus (2002).

Nessa perspectiva, o processo de não nomeação da mulher estuprada, mulher negra, pobre, é relevante para compreender como o sujeito-mulher é silenciado na/pela violência no seu corpo e na sua não nomeação. 
Assim, trazemos para análise a cena do filme Cidade de Deus (2002) que materializa, pela análise, os mesmos e diferentes sentidos, visto que a cena se instala como uma constatação de que o estupro tem menos a ver com o sexo em si e mais com o exercício de poder e de dominação masculina sobre o outro.

O filme Cidade de Deus $^{3}$ é narrado pelo personagem Buscapé, que deseja ser fotógrafo. Por sua narrativa, conhecemos outros personagens, como Zé Pequeno, que desde criança atuou como traficante até se tornar líder do tráfico. Para tanto, o personagem entra em disputa com Mané Galinha, personagem muito famoso, principalmente em meio às mulheres. É nesse processo de disputa pelo poder que Zé Pequeno ${ }^{4}$ protagoniza a cena de estupro como modo de impor-se e de vingar-se do seu oponente. A vítima do exercício de poder masculino é uma mulher, a namorada de Mané Galinha.

Para dar visibilidade a esse funcionamento, retornamos ao início do ato de estupro, narrado em off ${ }^{5}$, por Buscapé:

BUSCAPÉ: O problema de Zé Pequeno com Mané Galinha era muito simples, o Pequeno era feio, o Galinha bonitão. O Mané Galinha conquistava qualquer mulher. O Zé Pequeno só conseguia mulher pagando ou usando a força. A parada aí ó, era entre o bonitão do bem e o feioso do mal (CIDADE DE DEUS, 2002).

A descrição de Buscapé sobre os personagens Zé Pequeno e Mané Galinha materializa sentidos sobre as posições sujeito masculino. Assim, de um lado, temos a descrição de Mané Galinha, que representa o homem belo e "pegador", que sempre conquistava as mulheres, aspecto marcado no seu próprio nome, pois era alguém que se dava bem com todos, principalmente com as mulheres, constituindo a imagem de um homem sedutor, bonito e desejado. De outro lado, temos a descrição de Zé Pequeno, considerado "feio", que só conseguia mulher "pagando ou usando a força", o que marca o personagem pela prática do estupro.

Desse modo, é interessante compreender como se constrói, nessa descrição, uma dualidade entre o bem x o mal marcado pela/na aparência dos sujeitos homens, machos, um

\footnotetext{
${ }^{3}$ O filme Cidade de Deus, produzido por duas produtoras, Globo Filmes e Videofilmes, distribuído por Lumière Brasil, é uma adaptação da obra de mesmo nome, publicada em 1997, de Paulo Lins, sendo dirigido por Fernando Meirelles e Kátia Lund, em 2002.

${ }^{4}$ Ao final do filme, o personagem Zé Pequeno é assassinado por crianças que fazem, naquele momento, o tráfico no morro, tal como o personagem fizera um dia, produzindo o efeito de que o poder masculino apenas muda de mãos, pela reiteração dos acontecimentos, tanto no mundo do tráfico como no poder histórico dos homens sobre as mulheres.

5 "A $v o z$ off ou em off é aquele registro sonoro que faz parte da cena, mas que não aparece no quadro/enquadramento quando o público a escuta". Disponível em: <http://margofilmes.com.br/voz-over-vozoff-conheca-as-diferencas/>. Acesso em: 29 dez. 2018.
} 
que é o sedutor, que usa a sedução para as conquistas, tornando-se objeto de desejo, e o outro que, por ser feio, agride e violenta, para conseguir o que quer, estabelecendo uma relação mediada pelo pagamento. Essa dualidade se constitui historicamente por sujeitos marcados pela aparência: o que é feio está relacionado com a maldade, e o bonito com a bondade, pois, na narração de Buscapé, "Galinha é o bonitão do bem”, mesmo sendo chefe de tráfico, enquanto Zé Pequeno é o "feioso do mal”. A mudança de Galinha como homem de bem para a condição de traficante é também atribuída a Zé Pequeno e à rixa pelo poder do tráfico.

Assim, a trama do filme se desenrola em torno desses personagens centrais em disputa pela liderança "da boca" na Cidade de Deus, um tema que é recorrente nas comunidades do Rio de Janeiro e que se constitui no/pelo exercício de poder e de força masculina para traficar, matar, enfim, liderar a comunidade. O tema da disputa dos dois pelo poder é tão central que apaga a violência ocorrida contra uma mulher, a namorada de Galinha, vítima do estupro.

O acontecimento discursivo que antecede à cena do estupro é a recusa da namorada de Mané Galinha às investidas de Zé Pequeno, produzindo o efeito de que a recusa, o rechaço, a negação da mulher justifica, para o homem, a violência, pois esse comportamento aciona a memória de sentidos que foram produzidos alhures e que instalaram/instalam efeitos de que à mulher é dada a obrigação de satisfazer os desejos masculinos, pois a rejeição, o "não" como resposta, funciona como afronta à dignidade e ao poder masculino. São esses sentidos que constituem o ato de violência materializado por Zé Pequeno como vingança, pela rejeição sofrida, mas muito mais para mostrar dominação sobre o outro, o Mané Galinha.

É interessante observar que a mulher é tão irrelevante nesse processo que, no filme, a vítima de estupro é referida apenas como a "namorada de Mané Galinha”, ou seja, ela não tem nome, tem apenas um rosto, um corpo e gritos que significam o ato como violento.

O pronome "de" materializa sentidos de posse, em “de” Mané Galinha, ou seja, não há outra nomeação para a personagem, não há nome próprio, o que há é uma não nomeação, uma falta. Esse funcionamento é significativo para refletirmos sobre a constituição dos sujeitos e dos sentidos quando analisamos as condições históricas e sociais no Brasil. A mulher negra e pobre significa não só a interdição ao comportamento feminino, como também as relações entre classes e o racismo estrutural que constitui as discursividades no Brasil.

Esse funcionamento marca, no filme protagonizado por homens em disputa pelo poder do tráfico, a condição histórica dada à mulher, entretanto, mais especificamente a mulher negra. Assim, os sentidos de dominação patriarcal se dão por um silenciamento da condição feminina, que não se significa como esposa, filha, mas como escrava, sujeita a dominação de outrem. 
Nessas condições de produção, que põem em movimento a história, a mulher é apenas um objeto, um corpo a ser violentado, para acirrar a luta entre os homens, ou seja, mais uma vez o estupro não tem nada a ver diretamente com sexo, mas com o exercício, com a afirmação do poder de um sobre o outro, assim os desejos e vontades da mulher não são considerados, ou seja, não há nomeação da mulher, entretanto ela é significada, no filme, "na arte que imita a vida", pelo nome de outro: Mané Galinha.

Segundo Bernardes e Teixeira (2011), essa é uma personagem anônima, que aparece apenas como a "namorada de Mané Galinha", dessa maneira, "mal ouvimos sua voz, com exceção de dois momentos em que repele as investidas de Zé Pequeno" (BERNARDES; TEIXEIRA, 2011, p. 56).

A cena coloca em circulação algo maior que a humilhação sofrida por Mané Galinha, pois faz funcionar a memória de anomia dada às mulheres sobre seu corpo e seus desejos. A humilhação de Galinha é a de ser obrigado a assistir o ultraje de seu nome, pelo estupro de sua namorada por Zé Pequeno. Dito de outro modo, o que Pequeno sequestra, rapta é a dignidade, a propriedade de outro homem, então, o papel histórico da mulher nesse embate é o de ser o objeto da disputa, o que nos permite afirmar o estupro não como uma ocorrência do desejo puramente sexual, mas da disputa e do exercício de poder.

A namorada de Mané Galinha materializa, portanto, um modo de significar, no filme, uma identidade relacionada ao outro, sendo, assim, sua propriedade, então, o corpo violado da mulher é uma afronta ao seu dono, que é lesado em sua propriedade.

O papel da namorada de Mané Galinha resume-se a ser um elemento gerador da discórdia entre duas personagens masculinas. As consequências de seu estupro são enfocadas, na perspectiva do narrador-social, muito menos pelo sofrimento da vítima do que pela honra maculada de Mané Galinha (BERNARDES; TEIXEIRA, 2011, p. 58).

Nesse caso, a figura feminina não tem nome, não tem voz, não tem vontade, não tem poder sobre seu corpo, que é assumido como objeto de poder pelo homem, que a toma apenas como um meio, um objeto de disputa, um troféu a ser exibido como poder e posse.

\section{Apenas uma sombra: o estupro em Cidade de Deus}

A cena de estupro no filme Cidade de Deus (2002) é difusa, assim, a imagem é escurecida, ouvindo apenas os gritos da mulher eleita para o sacrifício. Como dissemos, a 
cena rememora uma condição histórica e social sobre a mulher no Brasil, que nos faz refletir sobre a relação de território, e nos modos como o estupro é significado no Brasil, pela historicização do sujeito-mulher pela colonização, escravidão, sentidos em fuga. Assim, a curta cena enfatiza o personagem Zé Pequeno com seu peito nu, suado, com seus colares em evidência, ritmado pelo movimento de ir e vir, de aparecer/desaparecer, exercitando, por seu dizer, o poder e a posse sobre o corpo feminino, mas corpo que é visto como de outro, de Mané Galinha, e Zé Pequeno presente no pronome "meu” em "Vem cá meu amor".

O corpo de Zé Pequeno se apresenta, às vezes, como foco, como centro da cena, em outras vezes, como um corpo desfocado, um corpo-sombra, que marca, pelo movimento, o poder, a dominação do corpo masculino sobre o feminino ao consolidar o estupro. Da mulher, da namorada do Mané Galinha, que não tem nome, que não tem corpo, só se ouve os gritos e, ao final, o choro.

Lagazzi (2015, p. 183) apresenta a contradição materializada na imagem que permite constituir a relação entre o intradiscurso e o interdiscurso. Desse modo, a autora reflete sobre a relação entre a "formulação visual na relação com o intradiscurso e a imagem na relação com o interdiscurso". Nessa direção, a formulação visual compõe a cena recortada do filme, já interpelada pelo interdiscurso, pois, ao mostrar parte do corpo de Zé Pequeno, produz um jogo entre mostra e esconde, entre o visível e o invisível. Esse funcionamento apresenta uma relação da imagem como algo que se constitui também na relação com o outro, pois há uma ilusão de que a imagem "fala mais do que mil palavras", os sentidos constituídos se dão pela interpelação ideológica que constitui a cena, produzindo seus efeitos.

A cena apresenta o modo como a mulher é apenas um objeto, uma mercadoria através da qual um homem marca/registra seu domínio sobre outro homem, pois possuí-la é possuir a propriedade de Galinha, do poder que ele tem sobre a boca no morro. Então, o filme reverbera sentidos da mulher como propriedade, como unidade, item de consumo, não do desejo, mas de poder, significando tanto a dominação do tráfico em um dos morros cariocas, quanto uma memória histórica da colonização e escravidão no Brasil.

No caso do filme, pode-se dizer que o estupro é usado como arma de guerra, guerra ocorrida na Cidade de Deus, comunidade do morro, no Rio de Janeiro, que se faz exclusivamente sobre o poder dos homens, um poder exercido de modo a tomar a mulher como objeto de demonstração desse poder.

Esse modo de constituição da cena é analisado por Milanez e Bittencourt (2012) no filme A dama de ferro, afirmando que é necessário que haja 
relação entre o movimento do corpo e de suas partes e o movimento da câmera, buscando identificar as singularidades e repetições evidenciadas nas ordens das narrativas e das formas de sucessão desses enunciados em torno destas materialidades imagéticas dadas (MILANEZ; BITTENCOURT, 2012, p. 11-12).

Na mesma direção, Lagazzi (2009; 2011; 2015), ao analisar documentários e filmes, dá visibilidade a esse funcionamento através da compreensão da imbricação de materialidades significantes: "O gesto analítico de recortar visa ao funcionamento discursivo, buscando compreender o estabelecimento de relações significativas entre elementos significantes" (LAGAZZI, 2009, p. 67).

Para a autora, os conceitos da Análise de discurso devem ser compreendidos e materializados na relação com as diferentes materialidades, produzindo diferentes análises decorrentes da especificidade de cada uma, pois as relações que o silêncio e o sujeito constituem em relação aos sentidos determinam "a relação do homem com as diferentes linguagens: horizontes, projetos de significar" (ORLANDI, 1995, p. 39).

Nesse foco, joga-se com o interlocutor do filme, pois, no modo como a câmera se localiza e se movimenta, coloca o espectador como aquele que detém o poder de dominação sob a mulher, visto que a cena toma o ponto de vista do personagem Zé Pequeno, que faz da mulher o objeto do exercício de seu poder, da sua capacidade de violentar, de estuprar o corpo feminino, não pelo desejo da carne, mas pela demonstração de poder, ou ainda, como o sujeito violentado, pois no modo de olhar produz tanto efeitos do ser dominador quanto do dominado.

De acordo com Julier e Marie (2009), a câmera pode colocar o espectador como testemunha, como um personagem na cena, ou articular entre momentos. Na cena em questão, a câmera busca produzir efeitos no espectador para que este se coloque no lugar do estuprador, que passa a ser reconhecido, ainda que pela indignação, como a materialização do mal, pois pouco lhe importa a mulher, uma vez que o que busca é subjugar, dominar o outro ao seu poder, ou ainda, como o sujeito violado. São projeções possíveis pelo recorte da cena.

Nestas conjunturas específicas, o corpo feminino não aparece, pois não tem relevância, uma vez que é o corpo masculino que sobressai, que está por cima, que segura, que subjuga, marcando seu domínio sobre o outro, no caso, um domínio exercido mais sobre Mané Galinha do que, propriamente, sobre a mulher que o rejeitou, produzindo um jogo entre mostrar e esconder. Mas a mulher está lá, seu corpo está lá, seus gritos, sua dor, sua tortura, assim, não mostrá-la produz mais efeitos de dominação do que se ela fosse mostrada, uma vez que a 
violência do estupro se constitui num lugar já tão naturalizado, que é natural que o corpo feminino seja subjugado, violentado como forma de atingir o outro.

A cena só é cortada para mostrar Mané Galinha, a imagem apresenta a figura de um pé segurando seu rosto para que veja o estupro, pois o estupro marca o poder de um sobre o outro, marca o domínio de Zé Pequeno sobre Mané Galinha, que é humilhado, tanto pela cena do estupro quanto pelo que Zé Pequeno vai dizendo: "Você vai ser minha hoje". A mulher sem nome é apenas um objeto de posse, de propriedade ora de Mané Galinha ora de Zé Pequeno, ou seja, é reificada como algo sem valor, como um mero objeto que se materializa apenas como um meio para a consecução de um fim.

Vemos nessa cena o pé centralizado, pois bloqueia um dos personagens forçando-o a assistir o ato de violência que ocorre no fundo da cena, que, por mais difusa, permite ao espectador saber que se trata do estupro da namorada do Mané Galinha por Zé Pequeno, ou seja, que estuprador e estuprada estão lá: uma pelos gritos e o outro pelo que diz: "Falei que você vai ser minha". Assim, o que a cena reitera é a humilhação de Mané Galinha e a mulher como objeto de posse, como propriedade silenciada em suas vontades, visto que é objeto da imposição do poder de um homem sobre o outro, o sujeito-mulher preso num jogo de poder. A afronta, então, não é contra a mulher, mas é direcionada ao outro homem, ao namorado, ao até então compreendido como dono de fato, inclusive pela nomeação. Ou seja, é a esse outro sujeito que o estupro se destina, pois é pela humilhação de Galinha que Zé Pequeno demonstra seu poder, sua força, fazendo do corpo da mulher a sua rama de luta e de vazão à inveja que sempre sentiu.

Dessa forma, o modo como o filme é produzido, como as imagens se movimentam e se significam constituem pontos importantes para a compreensão do discurso fílmico: "Atrás da câmera há o olho que controla o que podemos ver e maneira como podemos ver. A materialidade fílmica, nesse sentido, é marcada primeiro de tudo pela força daquele que imprime seu olhar sobre uma imagem que chegará até nós com recortes e edições." (MILANEZ; BITTENCOURT, 2012, p. 10-11).

Os movimentos, os recortes, a seleção dão visibilidade ao modo como diferentes materialidades atuam para produzir efeitos. Assim, o filme representa um funcionamento discursivo que se (re)significa por diferentes práticas, a partir de diferentes perspectivas e condições de produção.

Assim, a sandália branca, manchada, funciona como metáfora da violência daquele que pisa, que obriga, que impõe que o outro veja o seu poder, a sua dominação, a sua força e o que ela é capaz de fazer. O calçado/pé que pisa faz funcionar o poder de Zé Pequeno sobre 
Mané Galina, que é subjugado pelo pé que o obriga a olhar e a ser humilhado pelo estupro de sua namorada.

Da mulher, ao final da cena, ouvimos apenas o choro da humilhação e da dor sofrida pela violência física, uma violência que a atinge para além do corpo, uma violência que causa dor e sofrimento pelo sentimento de impotência, de vergonha, de culpa, pois, historicamente, a mulher foi responsabilizada pela violência praticada contra ela.

A sequência da cena mostra Mané Galinha se levantando, ao mesmo tempo em que sua companheira permanece chorando baixinho, mas agora eles são vultos, sombras do que foram. Desse modo, nessa cena, a imagem colocada em primeiro plano é a sombra de Mané Galinha, que fica imóvel diante da mulher estuprada, que está ao fundo, em segundo plano, como uma sombra que vai se apagando, dela mesma e de seu namorado. Assim, os dois planos da cena permitem compreender que a violência sofrida é posta também em segundo plano, pois o que sobrevém da cena de estupro é a motivação que instala a mudança no comportamento do personagem Mané Galinha, que, devido a esse acontecimento, torna-se um criminoso poderoso, para agir contra Zé Pequeno.

Nessa perspectiva, a imagem da mulher estuprada que se materializa nessa cena é apenas um vulto, uma sombra, "pálida à luz da lâmpada sombria", conforme o verso de Azevedo $^{6}$, que se associa, na memória, à cena da mulher estuprada por Zé Pequeno, pois se trata da imagem de uma mulher morta, apenas uma sombra, sem vida, pois seus sonhos foram silenciados pela dor e pela culpa.

Outra imagem que nos vem à memória é a do conto Para que ninguém a quisesse, de Marina Colasanti (2012), no qual o personagem masculino vai proibindo que a esposa vista roupas que ele considera sedutoras, corta-lhe os cabelos, enfim, a interdita de tal modo que a apaga, pouco a pouco. Assim, a formulação "mimetizada com os móveis e as sombras" (COLASANTI, 2012, p. 81) coloca em funcionamento o processo de apagamento da identidade feminina, pois a mulher torna-se um objeto entre outros, algo silenciado, algo colocado como uma sombra, sem brilho, sem vida.

Desse modo, há um processo de interdição que apaga a própria imagem feminina, pois a mulher não se identifica mais com o seu papel, visto que, ao ir morrendo aos poucos, resta dela apenas uma sombra, sem rosto, sem voz, sem vida, pois, pela interdição do sujeito, produz-se a "interdição da inscrição do sujeito em formações discursivas determinadas" (ORLANDI, 2007b, p. 76).

\footnotetext{
${ }^{6}$ Disponível em: <https://www.luso-poemas.net/modules/news03/article.php?storyid=476>. Acesso em: 29 dez. 2018.
} 
Na cena do filme, a última imagem da personagem que sofre o estupro é apenas uma sombra, assim, seu choro vai, aos poucos, diminuindo e sua imagem, mostrada como fundo da cena, vai se apagando, se tornando difusa, produzindo, através de sentidos metafóricos, a imagem da mulher como uma sombra, uma penumbra, uma imagem distorcida, que faz, contudo, mais forte e mais doído o seu sofrimento pela violência sofrida, pois a "a identidade do sujeito é imediatamente afetada enquanto sujeito-do-discurso" (ORLANDI, 2007b, p. 76).

\section{Considerações finais}

O estupro contra a mulher em Cidade de Deus é apenas o argumento, o gatilho que promove o embate, a disputa pelo poder entre os personagens masculinos. Dessa maneira, não é à namorada para quem Mané Galinha se volta, ela já está “contaminada”, já está morta, já não existe mais para ele, daí seu nome não ser relevante, pois ela era o nome de alguém até perdê-lo para o estupro. A personagem não tem nome, não tem voz, não demonstra desejos, assim, sua única fala no filme faz-se na cena de rejeição a Zé Pequeno, uma rejeição que, ao invés de engrandecê-la como uma mulher fiel ao seu companheiro, serve apenas de justificativa, de naturalização para o estupro praticado.

Desse modo, a cena de análise materializa a interdição do desejo feminino, da opressão sofrida pela mulher, da objetificação dos corpos e das relações de força, que se marcam pela divisão dos sentidos.

Dessa forma, o desejo feminino também é apenas uma sombra, pois não lhe está autorizado a desejar, ser, querer, pois não há nem um nome para a identificar, o que prevalece é o desejo do outro, marcando uma interdição para todas as mulheres, mas principalmente para a mulher negra que nem voz, nem nome, e, portanto, nem vez lhe é dado para resistir e assim se significar.

\section{Referências}

BERNARDES, Priscila Gonçalves; TEIXEIRA, Roberto Aparecido. Erotizadas e punidas: a representação das mulheres em Cidade Deus (2002). Revista do Laboratório de Estudos da Violência da UNESP, Marília, ed. 7, jun. 2011. Disponível em: <http://www.levs.marilia.unesp.br/revistalevs/edicao7/autores/4_ErotizadasPunidas.pdf>. Acesso em 23 jul. 2020. 
CIDADE DE DEUS: Filme. Brasil, 2002, drama. Direção: Fernando Meirelles, Roteiro: Braúlio Mantovani, Produção: Andréia Barata Ribeiro e Maurício Andrade Ramos, DVD, cor, 130 min., 2002.

COLASANTI, Marina. Um espinho de marfim e outras histórias. Porto Alegre: L\&M, 2012.

COSTA, Greciely Cristina. Discurso, cinema e cultura em suas práticas de significação: um relato sobre o Cineclube Nelson Mandela. In: ORLANDI, E. P.; MASSMANN, D. (Orgs.). Cultura e diversidade. Campinas: Pontes, 2016, p. 167-178.

GUIMARÃES, Eduardo. Semântica do Acontecimento: um estudo enunciativo da designação. 2 ed. Campinas: Pontes, 2005.

HASHIGUTI, Simone Tiemi; LEMES, Fabiane; PAIVA, Taís Iniz de. \#EuNãoMereçoSerEstuprada: o corpo feminino no dispositivo da violência. In: HASHIGUTI, S. T; TAGATA, W. M. (Orgs.). Corpos, Imagens e Discursos Híbridos. Campinas: Pontes, 2016, p. 119-137.

LAGAZZI, Suzy. O recorte significante da memória. INDURSKY, F.; FERREIRA, M. C. L.; MIITMAN, S. (Orgs.). O discurso na contemporaneidade: materialidades e fronteiras. São Carlos: Claraluz, 2009, p. 65-78.

LAGAZZI, Suzy. Paráfrases da imagem e cenas prototípicas: em torno da memória e do equívoco. In: FLORES, F. G. B.; NECKEL, N. R. M.; GALLO, S. M. L. (Orgs.). Análise de discurso em rede: cultura e mídia. Campinas: Pontes, 2015, p. 177-189.

JULLIER, Laurent; MARIE, Michel. Lendo as imagens do cinema. Tradução Magda Lopes. São Paulo: Senac, 2009.

MILANEZ, Nilton; BITTENCOURT, Joseane Silva. Materialidades da imagem no cinema: discurso fílmico, sujeito e corpo em A Dama De Ferro. Revista Movendo Ideias, v. 17, n. 2, p. 7-20, jul.-dez. 2012. Disponível em: <http://revistas.unama.br/index.php/MovendoIdeias/article/view/631>. Acesso em: 2 nov. 2017.

ORLANDI, Eni Puccinelli. Texto e discurso. Organon. Revista do Instituto de Letras da UFRGS, v. 9, n. 23, 1995, p. 111-118. Disponível em: <https://seer.ufrgs.br/organon/article/view/29365>. Acesso em: 11 jun. 2021. DOI: https://doi.org/10.22456/2238-8915.29365

ORLANDI, Eni Puccinelli. Discurso e texto: formulação e circulação dos sentidos. 2 ed. Campinas: Pontes, 2005.

ORLANDI, Eni Puccinelli. Análise de Discurso: princípios e procedimentos. 7 ed. Campinas: Pontes, 2007a.

ORLANDI, Eni Puccinelli. Interpretação: autoria, leitura e efeitos do trabalho simbólico. 5 ed. Campinas: Pontes, 2007b. 
ORLANDI, Eni Puccinelli; GUIMARÃES, Eduardo. Unidade e dispersão: uma questão do texto e do sujeito. In: ORLANDI, E. P. Discurso e leitura. 8 ed. São Paulo: Cortez, 2008, p. 53-76.

PÊCHEUX, Michel. O discurso: estrutura e acontecimento. 5 ed. Campinas: Pontes, 2008.

PÊCHEUX, Michel. Semântica e discurso: uma crítica à afirmação do óbvio. 4 ed. Campinas: Editora da UNICAMP, 2009.

PERROT, Michelle. Os silêncios do corpo da mulher. In: MATOS, M. I. S. de; SOIHET, R. (Orgs.). Corpo feminino em debate. São Paulo: UNESP, 2003, p. 13-28

PINTO, Danilo Corrêa. Corpos femininos produzidos pelo discurso da mídia para os desfiles de escolas de samba do carnaval carioca. In: HASHIGUTI, S. T.; TAGATA, W. M. (Orgs.). Corpos, imagens e discursos híbridos. Campinas: Pontes, 2016, p. 59-76

VIGARELLO, George. História do estupro: violência sexual nos séculos XVI-XX. Rio de Janeiro: Jorge Zahar Editor, 1998.

Recebido em: 10 de julho de 2021

Aceito em: 30 de setembro de 2021 